\title{
Optimization of some fermentation conditions for bioethanol production from microalgae using response surface method
}

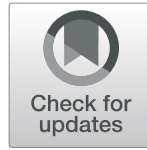

Samar A. El-Mekkawi ${ }^{*}$ (D), Sayeda M. Abdo², Farag A. Samhan² and Gamila H. Ali²

\begin{abstract}
Background: Algal biomass fermentation is one of the promising alternatives for bioethanol production. The bioethanol yield relies on fermentation conditions as the algal biomass amount, the yeast volume $(\% \mathrm{v} / \mathrm{v})$, and the fermentation time. In this work, algal biomass harvested from a pilot-scale high rate algal pond (HRAP) was fermented anaerobically using immobilized Saccharomyces cerevisiae (ATCC 4126). The HRAP was constructed at the Zenin wastewater treatment plant (WTP), Giza, Egypt. A separate hydrolysis fermentation process (SHF) was applied for algal biomass. The effect of the algal biomass amount, the yeast volume $(\% \mathrm{v} / \mathrm{V})$, and the time of fermentation as three independent variables were studied simultaneously and analyzed statistically using Design-Expert software V6.0.8.

Results: The harvested algal biomass from HRAP contains $45 \%$ carbohydrates and was dominated by Microcystis sp. The results revealed that optimum bioethanol yield $18.57 \mathrm{~g} / \mathrm{L}$ is achieved by fermenting $98.7 \mathrm{~g} / \mathrm{L}$ algae using $15.09 \%$ of the volume immobilized yeast for $43.6 \mathrm{~h}$ with a $95 \%$ confidence interval.

Conclusion: Microalgae grown on wastewater are a promising source of bioethanol production. Maximizing the ethanol production is achieved by optimizing the fermentation parameters as algal biomass, fermentation time, and yeast volume percent. The simultaneous optimization of the parameters using a statistical program is an effective way to maximize the production and predict a model that describes the relationship between these parameters and their response. The prospective research is going to study the effect of these predicted parameters on continuous fermentation on the semi-pilot scale.
\end{abstract}

Keywords: High rate algal pond, Bioethanol, Saccharomyces cerevisiae, Immobilized yeast, Fermentation time

\section{Background}

The concern for the deleterious effect of fossil fuels on the environment obliges the society to reduce greenhouse gas emissions via creating renewable fuel alternatives (Demirbas 2009, Wolske and Stern 2018, Jorgenson et al. 2019). Among renewable energies, the preference was given to liquid biofuels as it represents about $40 \%$ of the total energy consumption in the world (Tan et al. 2008). The global ethanol production has been altitude from 13.12 billion gallons in 2007 to 27.05 billion gallons in 2017 with a slight reduction in 2012 and 2013 (Renewable Fuels Association US 2018). Bioethanol can be used as it is or blended with gasoline to form "gasohol"

\footnotetext{
*Correspondence: samarelmekkawi@hotmail.com

${ }^{1}$ Chemical Engineering and Pilot Plant Department, National Research

Centre, Giza 12622, Egypt

Full list of author information is available at the end of the article
}

(Staniszewski et al. 2007). Also, it can be used as a gasoline improver or octane enhancer and in bioethanoldiesel blends to reduce the emission of exhaust gasses (Pejin et al. 2009). In contrast to petroleum fuel, bioethanol is readily biodegradable, less toxic, and emits lesser airborne pollutants (John et al. 2011).

Algal growing in wastewater can significantly share in the management of freshwater ecosystems and treat wastewater. The integrated algal system has other advantages than wastewater treatment depending on the algal community as a source of biofuel production. Microalgae are a potential feedstock for bioethanol production, as they possess high concentrations of carbohydrates (11-50\%) in the form of starch and cellulose, which can be fermented to bioethanol (Lu et al. 2001, Yusuf 2007, Silva and Bertucco 2016, Doma et al. 2018, Silva et al. 2018). Microalgal carbohydrates lack lignin, which makes 
their conversion to monosaccharides much easier compared to lignocellulosic materials (John et al. 2011).

Bioethanol can be produced from micro-algal biomass via a fermentation process by Saccharomyces cerevisiae (Nigam and Singh 2011), the common microbe used in ethanol production according to its ability to ferment a wide range of sugars, its high ethanol tolerance, and its high ethanol productivity (Kasavi et al. 2012, Lin et al. 2012). The efficiency and productivity of ethanol can be enhanced by immobilizing the yeast cells (Jin and Speers 1998, Domingues et al. 2000). It reduces the cost of cell recovery as it separates easily from the fermentation medium without centrifugation (Choi et al. 2010). Production of bioethanol during fermentation depends on several factors such as inoculum size, sugar concentration, agitation rate, temperature, $\mathrm{pH}$, and fermentation time (Attfield 1997), Tofighi et al. 2014).

In this work, three independent parameters algal biomass, percent yeast volume, and fermentation time which significantly affect the fermentation yield were investigated. A model that describes the bioethanol production as a function of the studied parameters was created. Most prior research has studied these parameters separately, simply one of the three parameters was invariably kept constant while varying the other, thus hindering the opportunity of any potential interaction between the three factors. In this respect, designing experiments using response surface methodology (RSM) allows studying the simultaneous influence of several parameters through statistical methods. One of the merits of that system is the possibility of determining any nonlinear relationships between the independent variables (Montgomery 2003). This step was enhanced by establishing a model for predicting the bioethanol production.

\section{Material and methods}

\section{The algal biomass production system}

An integrated system was constructed at the Zenin wastewater treatment plant (WTP), Egypt. This system consists of a primary facultative pond followed by the high rate algal pond (HRAP) with dimensions of $7.5 \mathrm{~m} \times$ $2.4 \mathrm{~m} \times 0.3 \mathrm{~m}(\mathrm{~L} \times \mathrm{W} \times \mathrm{H})$ and active volume of $5.4 \mathrm{~m}^{3}$. The inlet of the system was fed from Zenin WTP influent after physical treatment (screening) as illustrated in Fig. 1 followed by a facultative pond where the organic matter was decomposed by bacteria.

Algal biomass grew in HRAP along the operating period from June to December 2017 and was dominated by Microcystis sp. A microscopical investigation for the algal community was carried out three times a week. Harvesting was carried out through coagulation by cationic starch $(10 \mathrm{mg} / \mathrm{L})$ followed by settling for an hour (El-Naggar et al. 2018). The precipitated algae were collected and dried using a solar dryer. The dried algal biomass was hydrolyzed to digest the complex sugars preparing it for fermentation via immobilized Saccharomyces cereviciae (ATCC 4126).

\section{Immobilized yeast preparation}

The inoculum was prepared by transferring the S. cerevisiae cells into the yeast peptone dextrose broth media (YPD-Himedia, M1363) then incubated the cultures at $37^{\circ} \mathrm{C}$ for $48 \mathrm{~h}$. The yeast culture was centrifuged at $4000 \mathrm{rpm}$; the settled pellets were suspended in $0.9 \%(\mathrm{w} /$ v) $\mathrm{NaCl}$ solution then centrifuged and immobilized in $\mathrm{Na}$-alginate. The yeast cells were immobilized in $\mathrm{Na}-\mathrm{al}-$ ginate as described by El-Dalatony et al. (2016). The 2\% $(\mathrm{w} / \mathrm{v}) \mathrm{Na}$-alginate solution was prepared by dissolving 7 $\mathrm{g}$ of $\mathrm{Na}$-alginate powder (Alfa Aeser) into $360 \mathrm{~mL}$ of distilled water by gradual adding the powder into the bottle while gently steering. Ninety milliliters of yeast biomass suspension was gently added to the $\mathrm{Na}$-alginate mixture and mixed thoroughly at room temperature. This mixture was extruded drop-wisely through a $50-\mathrm{mL}$ burette to the $\mathrm{CaCl}_{2}(2.65 \% \mathrm{w} / \mathrm{v})$ solution to prepare uniform spherical beads $(\approx 0.4 \mathrm{~mm}$ diameter $)$. The resulting beads were then washed with distilled water

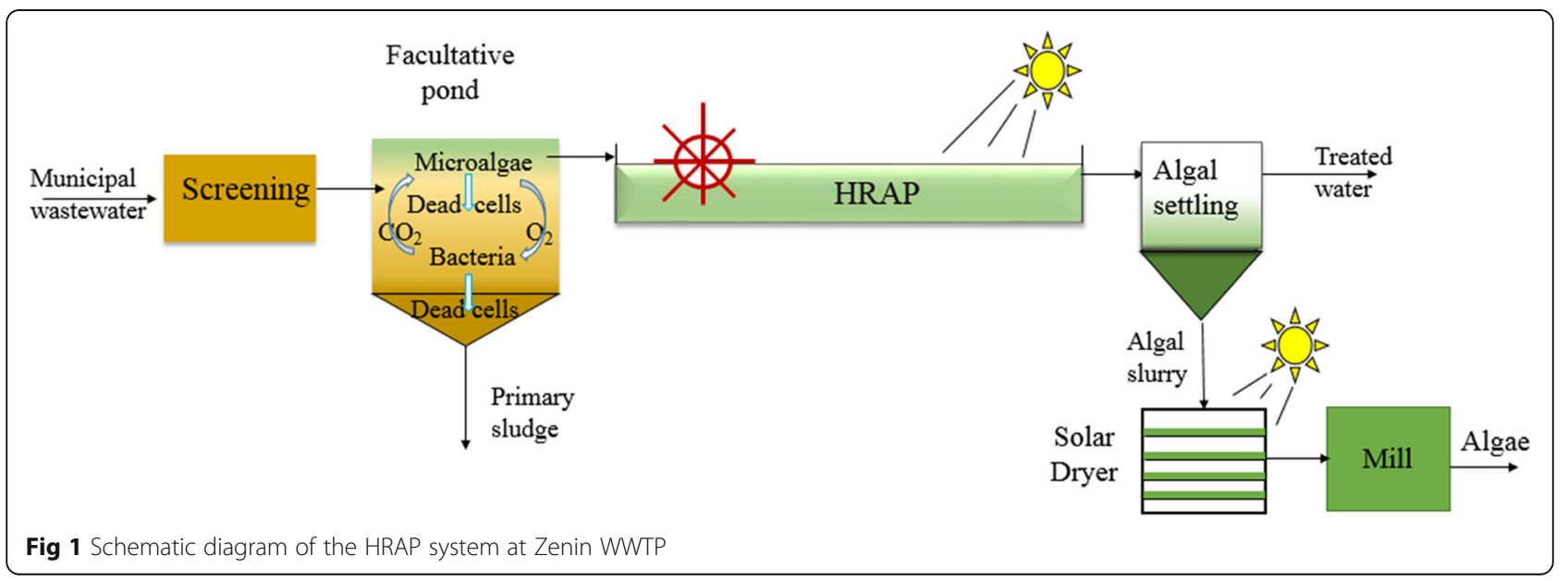


two to three times to remove the impurities and stored at $4{ }^{\circ} \mathrm{C}$ for $10 \mathrm{~min}$ for hardening.

\section{Acid hydrolysate preparation of microalgal biomass}

The feed stream was hydrolyzed using $0.5 \mathrm{~N} \mathrm{H}_{2} \mathrm{SO}_{4}$ for $4 \mathrm{~h}$ at temperature $120^{\circ} \mathrm{C}$. The hydrolyzed biomass was subsequently adjusted to $\mathrm{pH} 4.5( \pm 0.1)$ with $\mathrm{NaOH}$ at temperature $30^{\circ} \mathrm{C}$ then filtrated. The carbohydrate concentration was measured for the hydrolysate by spectrophotometer (Cary 100 UV-Vis) at $485 \mathrm{~nm}$ (Dubois et al. 1956).

\section{Fermentation}

The hydrolysate of algal biomass was fermented anaerobically with immobilized S. cerevisiae at $30 \pm 2{ }^{\circ} \mathrm{C}$. The algal hydrolysate was covered with paraffin film to ensure an anaerobic condition. Fermentation processes were implemented in three parallel containers $500 \mathrm{~mL}$ each and operated at the same time to unify the conditions. Bioethanol produced was separated from the aqueous solution by evaporation at $70^{\circ} \mathrm{C}$ using the rotary evaporator where the condensed bioethanol was collected under the ice to avoid re-evaporation (Khalil et al. 2015).

The ethanol purity was measured calorimetrically using the potassium dichromate method (Crowell and Ough 1979) by adding $2 \mathrm{~mL}$ of distilled sample to $10 \mathrm{~mL}$ of acidic potassium dichromate reagent and mixed well. The tubes were capped and kept in a water bath at $60^{\circ} \mathrm{C}$ for $20 \mathrm{~min}$ then cooled to room temperature. The absorption of the reaction mixture was measured at 600 $\mathrm{nm}$ by spectrophotometer (Cary $100 \mathrm{UV}$-Vis). The potassium dichromate reagent was prepared by dissolving $34 \mathrm{~g}$ of potassium dichromate $\left(\mathrm{K}_{2} \mathrm{Cr}_{2} \mathrm{O}_{7}\right)$ in $400 \mathrm{~mL}$ distilled water with $325 \mathrm{~mL}$ of sulfuric acid and by making up the volume to $1 \mathrm{~L}$. A standard curve was prepared under similar conditions using standard solutions of ethanol in distilled water (Khalil et al. 2015). The fermentation yield percent is calculated as follows (Silva et al. 2018):

Fermentation yield $\%=[$ Ethanol produced $/(0.511 \times \Delta$ sugars $)] \times 100$

\section{Response surface methodology}

The algal biomass, the incubation time of fermentation, and the volume ratio of yeast to the algal substrate are considered the most significant parameters affecting the bioethanol production (Attfield 1997, Choi et al. 2010, Tofighi et al. 2014). The range of the examined algal biomass was $30-100 \mathrm{~g} / \mathrm{L}$. The selected range of incubation time was $24-72 \mathrm{~h}$. The volume ratio of immobilized yeast to the algal substrate was ranged from 1:10 to $1: 1$, i.e., yeast occupies a range of $15-50 \%$ of the total volume. The RSM was chosen as a suitable route for optimizing the interactive effect of algal biomass $(G)$, the fermentation time $(T)$, and the yeast volume percent $(V)$ simultaneously on the bioethanol production.

The experimental results were statistically analyzed and modeled using the RSM via Design-Expert 6.0.8 software during a trial period. The extent of the fit of the model was evaluated using the normal plot of residuals and the analysis of variance (ANOVA).

\section{Results}

The effects of algal biomass $(G)$, the fermentation time $(T)$, and the yeast volume $\% \mathrm{v} / \mathrm{v}(V)$ were studied as the three independent variables affecting bioethanol production in a total of 20 experiments through a central composite design as shown in Table 1 . The data were analyzed using Design-Expert 6.0.8 software. Table 2 describes the ANOVA for the response surface of a quadratic model for bioethanol response. The analysis of the response yielded 3 linear coefficients $(G, V, T)$, three quadratic coefficients $\left(G^{2}, V^{2}, T^{2}\right)$, and three crossproduct coefficients for the full model $(G \times V, G \times T, V$ $\times T)$. The statistical analysis of the response revealed that the regression coefficient $\left(R^{2}\right)$ was 0.998 , whereas the predicted $R^{2}$ was 0.992 and the adjusted $R^{2}$ was 0.997 with a coefficient of variation (CV) of 1.5 . The probability of $F$ function for each model term is less

Table 1 Experimental data for central composite design

\begin{tabular}{llllll}
\hline Run & $\begin{array}{l}\text { Algal } \\
\text { biomass, } \\
\text { g/L }\end{array}$ & $\begin{array}{l}\text { Yeast } \\
\text { volume } \\
\% \text { v/v }\end{array}$ & $\begin{array}{l}\text { Fermentation } \\
\text { time, } h\end{array}$ & \multicolumn{2}{l}{ Bioethanol production, $\mathrm{g} / \mathrm{L}$} \\
\cline { 6 - 6 } 1 & 65.00 & 3.07 & 48.00 & 18.53 & 18.49 \\
2 & 100.00 & 50.00 & 24.00 & 13.82 & 13.88 \\
3 & 30.00 & 15.00 & 72.00 & 13.04 & 12.98 \\
4 & 65.00 & 32.50 & 88.36 & 13.49 & 13.32 \\
5 & 6.14 & 32.50 & 48.00 & 3.92 & 4.04 \\
6 & 65.00 & 32.50 & 7.64 & 10.98 & 11.15 \\
7 & 65.00 & 32.50 & 48.00 & 14.17 & 14.20 \\
8 & 65.00 & 32.50 & 48.00 & 14.05 & 14.20 \\
9 & 65.00 & 32.50 & 48.00 & 14.20 & 14.20 \\
10 & 65.00 & 32.50 & 48.00 & 14.50 & 14.20 \\
11 & 123.86 & 32.50 & 48.00 & 15.04 & 14.92 \\
12 & 100.00 & 15.00 & 24.00 & 18.01 & 17.90 \\
13 & 30.00 & 15.00 & 24.00 & 8.00 & 8.00 \\
14 & 100.00 & 15.00 & 72.00 & 17.76 & 18.00 \\
15 & 30.00 & 50.00 & 72.00 & 8.33 & 8.44 \\
16 & 65.00 & 32.50 & 48.00 & 14.15 & 14.20 \\
17 & 65.00 & 61.93 & 48.00 & 11.24 & 11.28 \\
18 & 65.00 & 32.50 & 48.00 & 14.10 & 14.20 \\
19 & 100.00 & 50.00 & 72.00 & 11.46 & 11.46 \\
20 & 30.00 & 50.00 & 24.00 & 6.21 & 5.97 \\
\hline & & & & & \\
\hline
\end{tabular}


Table 2 ANOVA results for the quadratic model

\begin{tabular}{llll}
\hline Source & DF & F-value & Prob $>F$ \\
\hline Model & 9 & 831.63 & $<0.0001$ \\
A & 1 & 3882.78 & $<0.0001$ \\
B & 1 & 1702.62 & $<0.0001$ \\
C & 1 & 153.10 & $<0.0001$ \\
$A^{2}$ & 1 & 1088.45 & $<0.0001$ \\
$B^{2}$ & 1 & 23.30 & 0.0007 \\
$C^{2}$ & 1 & 188.10 & $<0.0001$ \\
AB & 1 & 54.08 & $<0.0001$ \\
AC & 1 & 324.27 & $<0.0001$ \\
BC & 1 & 85.95 & $<0.0001$ \\
Lack of fit & 5 & 1.93 & 0.2446 \\
$R^{2}$ & 0.998 & & \\
Adjusted $R^{2}$ & 0.997 & & \\
Predicted $R^{2}$ & 0.992 & & \\
C.V & 1.5 & &
\end{tabular}

than 0.05 which verifies the significance of all the model terms, while the probability of $F$ function for the lack of fit is greater than 0.05 which verifies the nonsignificance of error.

The regression equation of the bioethanol production response in terms of the actual variables is as follows:

$$
\begin{aligned}
& \text { Bioethanol production, } \mathrm{g} / \mathrm{L} \\
& =-5.39+(0.37 \times G)-(0.05 \times V) \\
& \quad+(0.29 \times T)-\left(1.3 \times 10^{-3} \times G^{2}\right) \\
& \quad+\left(8 \times 10^{-4} \times V^{2}\right)-\left(1.2 \times 10^{-4} \times T 2\right) \\
& \quad-(0.003 \times G \times V)-(0.002 \times G \times T) \\
& \quad+(0.003 \times V \times T)
\end{aligned}
$$

The predicted model is verified experimentally through the actual values of the bioethanol production and the equivalent predicted values as shown in Table 1. The optimum predicted result is $18.57 \mathrm{~g} / \mathrm{L}$ that is shown in Table 3 and was verified experimentally through triplicate fermentation experiment for $65 \mathrm{~g} / \mathrm{L}$ algal biomass, 32.5 yeast volume $\% \mathrm{v} / \mathrm{v}$, and $43.6 \mathrm{~h}$. The actual results were $18.54 \mathrm{~g} / \mathrm{L}, 18.56 \mathrm{~g} / \mathrm{L}$, and $18.58 \mathrm{~g} / \mathrm{L}$ with an average value of $18.56 \mathrm{~g} / \mathrm{L}$. The statistical analysis of all verified values with $p=0.05$ are stated in Table 2 . The normal plot of the residuals of this model is displayed in Fig. 2 to evaluate the distribution of residuals. The simultaneous effect of algal biomass and fermentation time on bioethanol production at the central point of yeast volume $\% \mathrm{v} / \mathrm{v}$ is represented in Fig. 3, while the simultaneous effect of yeast volume $\% \mathrm{v} / \mathrm{v}$ and fermentation time at the central point of algal biomass on bioethanol production is exhibited in Fig. 4 and the simultaneous effect of algal biomass and yeast volume $\% \mathrm{v} / \mathrm{v}$ at the central point of time on bioethanol production is presented in Fig. 5. The predicted optimum value of bioethanol production after $43.6 \mathrm{~h}$ of fermentation time is $18.57 \mathrm{~g} / \mathrm{L}$; this value is predicted by fermenting $65 \mathrm{~g} / \mathrm{L}$ algal biomass and 32.5 yeast volume \% v/v.

\section{Discussion}

The merit of using the response surface method is to study more than one parameter simultaneously. However, selecting the parameters and their range values depends on their high significant effect on bioethanol production and their influence on each other. There is no doubts that high algal biomass need a high amount of yeast volume $\% \mathrm{v} / \mathrm{v}$ through adequate time to maximize the produced bioethanol. On the other hand, high bioethanol concentration causes yeast deterioration. This may happen via a long time process or high algal biomass concentration (Markou et al. 2013, Ho et al. 2013, Ashokkumar et al. 2015).

The fermentation yield \% measured by Markou et al. (2013) is $56 \%$ by fermenting $12-13 \mathrm{~g} / \mathrm{L}$ acidic hydrolysate biomass of Antrosphira platensis, while the fermentation yield \% measured by Ho et al. (2013) is $90 \%$ by fermenting $10-80 \mathrm{~g} / \mathrm{L}$ acidic hydrolysate biomass of Chlorella vulgaris. In this work, the fermentation yield \% is $90 \%$ for fermenting $30 \mathrm{~g} / \mathrm{L}$ of acidic hydrolyzed biomass in conditions of run 20. At the same conditions of biomass and yeast volume $\% \mathrm{v} / \mathrm{v}$ in run 15 , the bioethanol production increases by increasing the fermentation time. Decreasing the yeast volume \% in run 3 causes increasing bioethanol production. In this condition of the lowest biomass concentration, low yeast volume \% and high time range increase the bioethanol production.

Fermenting the central value of $65 \mathrm{~g} / \mathrm{L}$ algal biomass, the fermentation yield \% is $90 \%$ in run 4 for fermentation time $88.36 \mathrm{~h}$. The yield \% increased to $94 \%$ as the time decreased to $48 \mathrm{~h}$ in run 7 at the same \% yeast volume $32.5 \%$. The yield \% decreased to $61.93 \%$ as a consequence of increasing the yeast volume $\%$ to $61.93 \%$ in run 17 . This reverse relation is implemented in run 1 too, where the yield \% increases as the yeast volume $\%$ decreases.

The high border of algal biomass $100 \mathrm{~g} / \mathrm{L}$ is fermented in various conditions. The bioethanol production records the minimum value of $11.46 \mathrm{~g} / \mathrm{L}$ at high fermentation time

Table 3 Statistical analysis of the predicted solutions

\begin{tabular}{llllll}
\hline & Prediction & $95 \%$ Cl low & $95 \%$ Cl high & $95 \%$ Pl low & 95\% PI high \\
\hline Bioethanol production, g/L & 18.57 & 18.32 & 18.83 & 18.08 & 19.07 \\
\hline
\end{tabular}




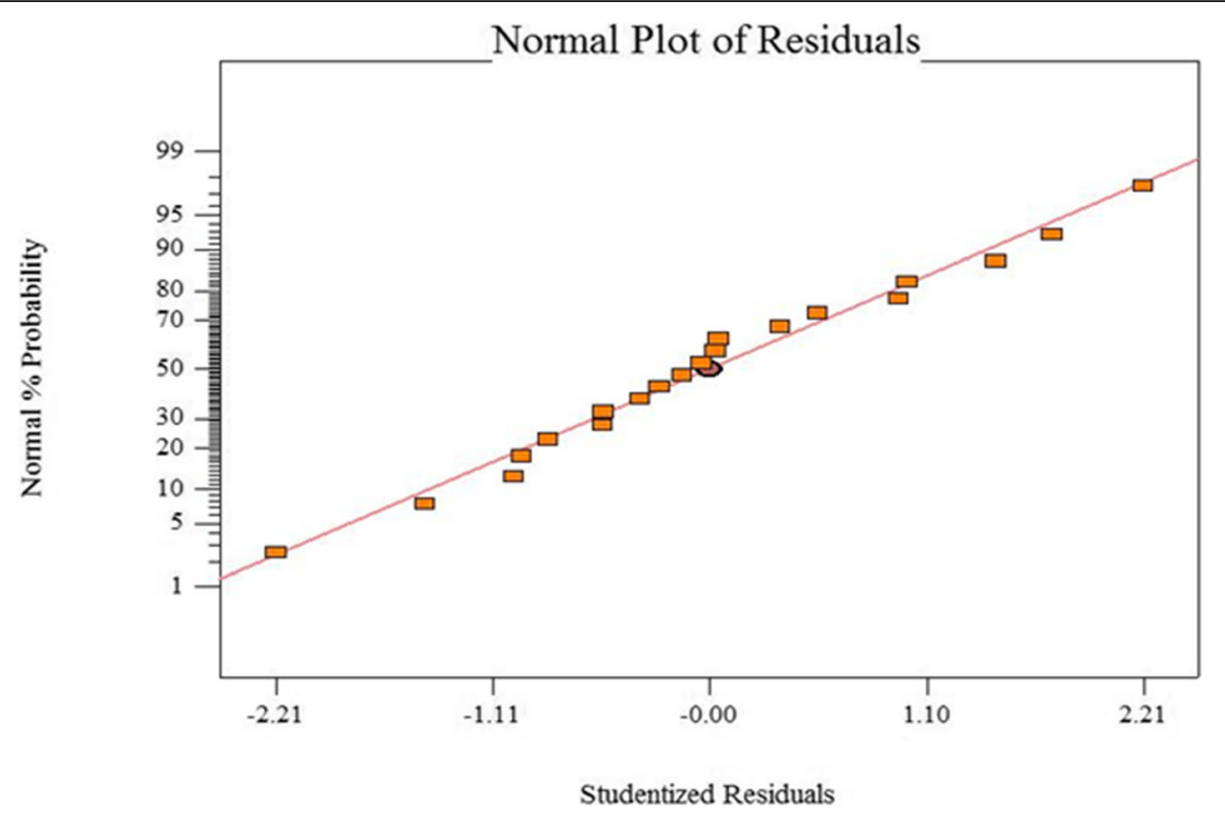

Fig 2 The normal plot of the residuals

of $72 \mathrm{~h}$ in run 19. The yield increase in run 2 is a consequence of decreasing the time to $24 \mathrm{~h}$. Decreasing the yeast volume \% to the minimum limit causes the increasing of the bioethanol production in run 14 at time $72 \mathrm{~h}$ and increased more in run 12 at time $24 \mathrm{~h}$. According to the wide variance in the fermentation yield \%, it is necessary to optimize the studied parameters simultaneously. The most effective route to optimize these parameters is RSM.

In this work, the interactive effect of algal biomass $(G)$, fermentation time $(T)$, and \% yeast volume on the bioethanol production was investigated using RSM. The statistical analysis of the response revealed that the predicted $R^{2}$ is in harmony with the adjusted $R^{2}$. The analysis of variance (Table 2) for the partial sum of squares illustrated that the model $F$-value of 831.63 implies the model is significant and the values of Prob $>F$ are less than 0.05 indicating that the model terms are significant, whereas the lack of fit $F$-value of 1.93 implies the lack of fit is not significant which indicates that the model can accurately predict the relationships between the reaction factors within the selected range.

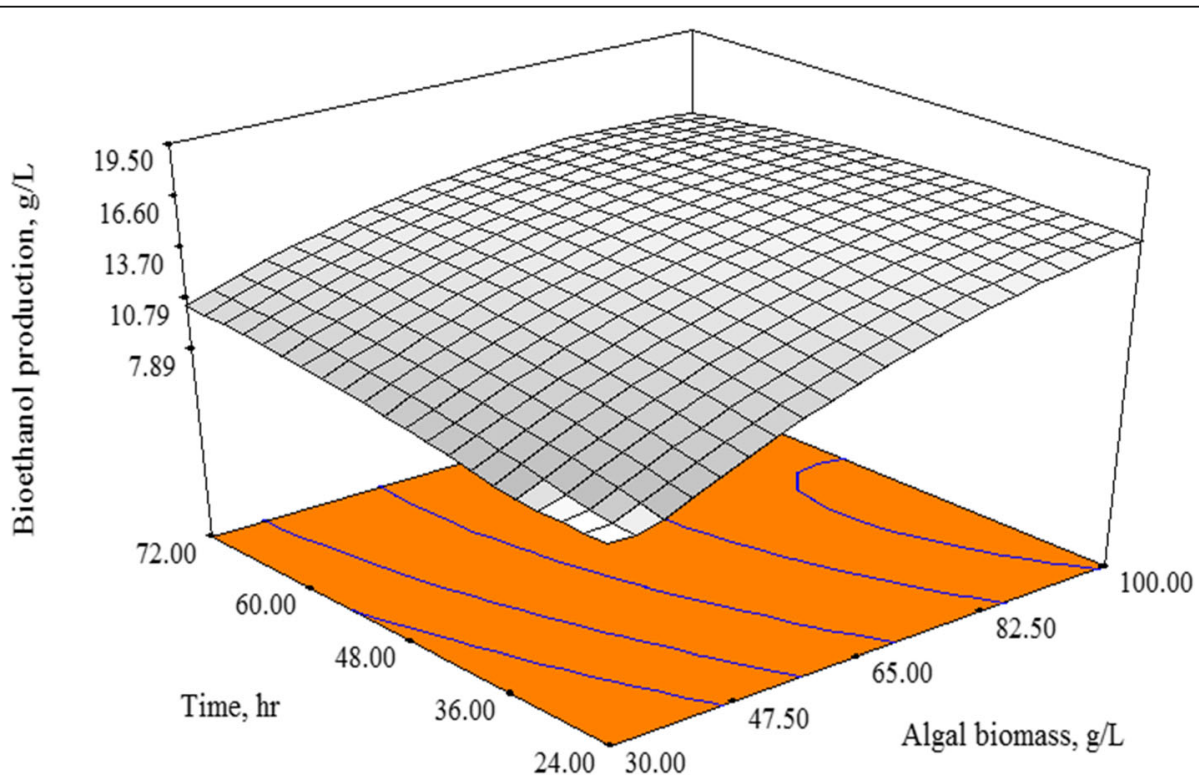

Fig. 3 The simultaneous effect of algal biomass and time on bioethanol yield at the central point of yeast volume $\% \mathrm{v} / \mathrm{V}$ 


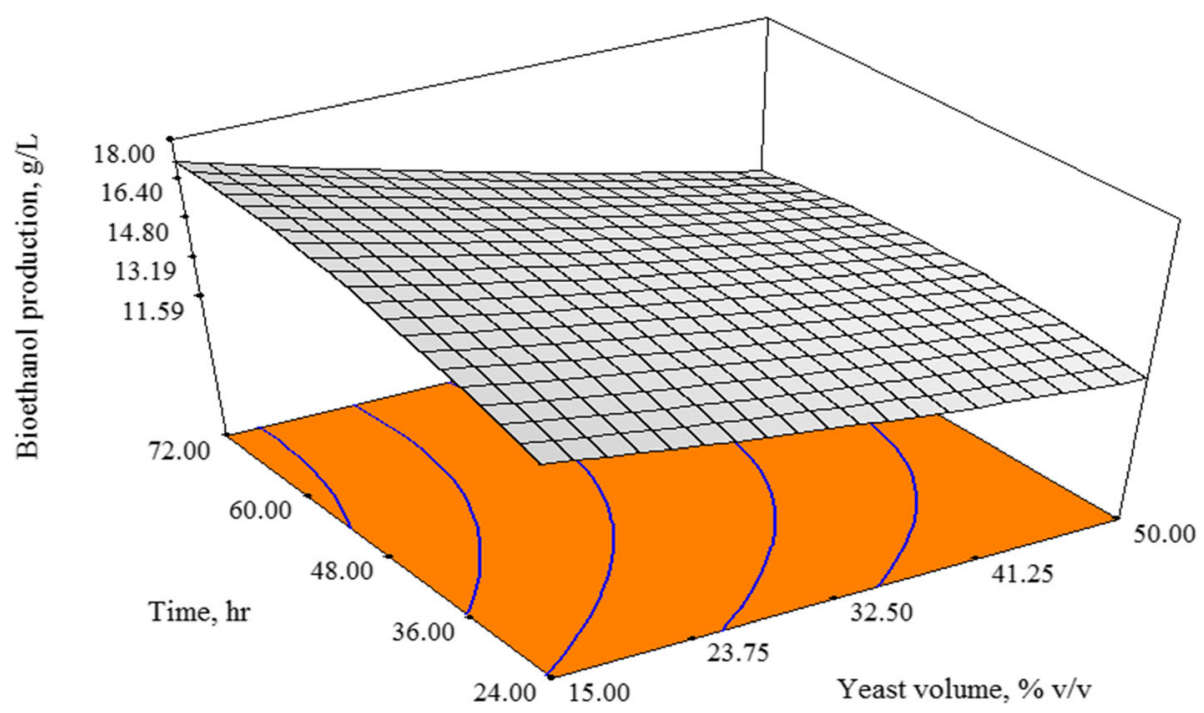

Fig 4 The simultaneous effect of yeast volume $\% \mathrm{v} / \mathrm{v}$ and time on bioethanol yield at the central point of the algal biomass

High variance is noticed as the coefficient of variation (C.V.) which is greater than 1 indicating that the data points are very spread out from the mean and from one another. The normal plots of the residuals are approximately linear verifying a normal distribution of the error terms. The optimum production of bioethanol was predicted with a prediction interval of $95 \%$ and a confidence interval of $95 \%$.

The contour graphs in Figs. 3, 4, and 5 implemented the optimum values of this model. The maximum bioethanol production in Fig. 3 is $16.5-18.5 \mathrm{~g} / \mathrm{L}$ at the central yeast volume $\%$ of $32.5 \% \mathrm{v} / \mathrm{v}$; this was achieved at a range of algal biomass of $90-100 \mathrm{~g} / \mathrm{L}$ and fermentation time of $24-50 \mathrm{~h}$. This is in agreement with Silva et al. (2018) since increasing the time factor increases the fermentation yield up to a limit of high bioethanol concentration relative to the yeast amount; this explains the declination of the curve beyond these values. The relation between the fermentation time and yeast volume $\%$ was exhibited in Fig. 4 where the trapped area of 40 $72 \mathrm{~h}$ and $15-20 \% \mathrm{v} / \mathrm{v}$ produced the highest bioethanol production $(15-17 \mathrm{~g} / \mathrm{L})$ at the central algal biomass $65 \mathrm{~g} /$ L. This result is in harmony with El-Dalatony et al. (2016) and Silva et al. (2018), where the low yeast

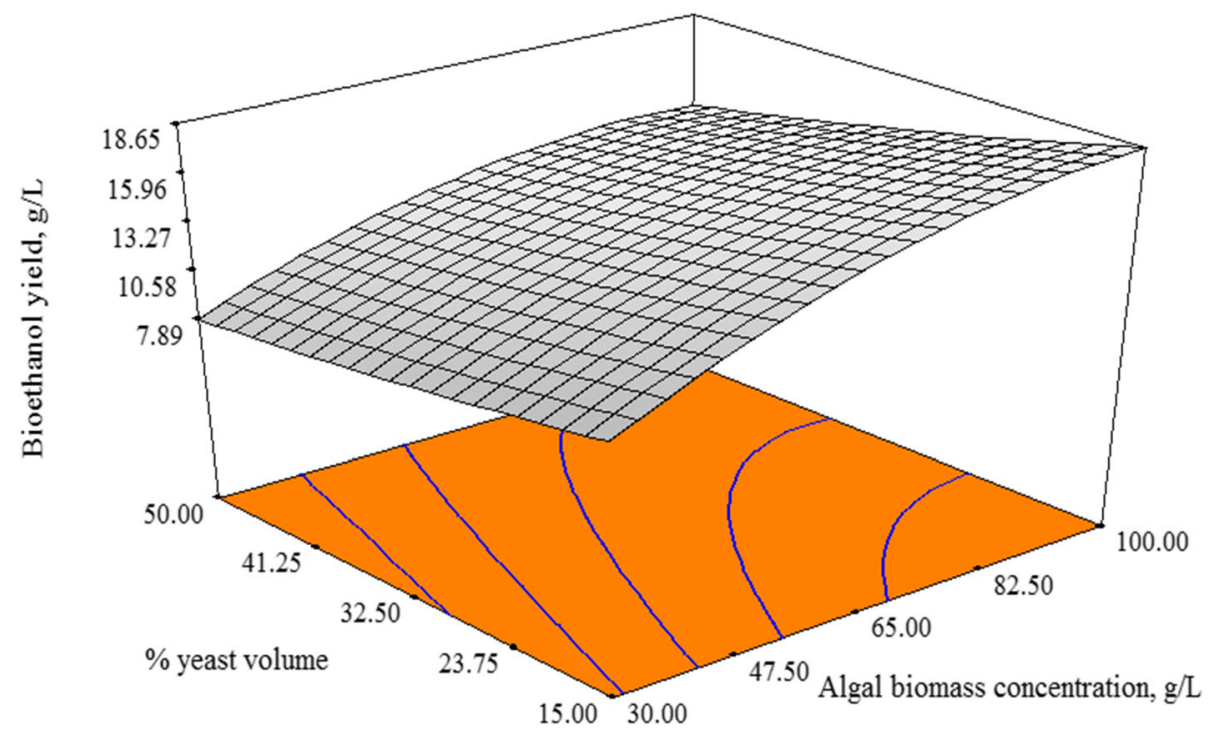

Fig 5 The simultaneous effect of yeast volume $\% \mathrm{v} / \mathrm{v}$ and algal biomass concentration on bioethanol yield at the central point of the time 
volume $\% \mathrm{v} / \mathrm{v}$ requires higher time for bioethanol production. Finally, Fig. 5 shows the optimum conditions are $70-100 \mathrm{~g} / \mathrm{L}$ and $15-20$ yeast volume $\% \mathrm{v} / \mathrm{v}$ for bioethanol production $(16-18.65 \mathrm{~g} / \mathrm{L})$ at the central point of time of $48 \mathrm{~h}$. The combination of the three modules represented by the previous figures was solved by the Design-Expert program that implements the optimum area of the three parameters located in the range of $90-100 \mathrm{~g} / \mathrm{L}, 15-20$, and $40-50 \mathrm{~h}$.

The optimum predicted bioethanol concentration calculated using RSM via the design expert program is $18.57 \mathrm{~g} / \mathrm{L}$ through fermenting $98.7 \mathrm{~g} / \mathrm{L}$ algal biomass by 15.09 yeast volume $\% \mathrm{v} / \mathrm{v}$ for $43.6 \mathrm{~h}$ fermentation time. The bioethanol to algae ratio is $0.188 \mathrm{~g} / \mathrm{g}$, while the ratio obtained by fermenting Scenedesmus abundans using 3\% $\mathrm{v} / \mathrm{v}$ S. cerevisiae for $48 \mathrm{~h}$ is $0.103 \mathrm{~g} / \mathrm{g}$ (Guo et al. 2013), whereas fermenting Chlorella vulgaris using Zymomonas mobilis produces $0.178 \mathrm{~g}$ ethanol $/ \mathrm{g}$ algae using SHF process (Ho et al. 2013). These lower values may be due to the small amount of yeast. On the other hand, fermenting Chlorococum sp. via Saccharomyces bayanus produces $0.38 \mathrm{~g}$ ethanol $/ \mathrm{g}$ algae (Harun et al. 2010). This higher value was achieved at a small algal amount $(10 \mathrm{~g} / \mathrm{L})$ and a high yeast amount $(3 \mathrm{~g} / \mathrm{L})$ which is not applicable on a large scale. According to the lack of data about bioethanol productivity from Microcystis sp., it was effective to use RSM to minimize the number of experiments and perform an operative prediction model that describes the relationship between the studied parameters.

\section{Conclusions}

The effects of algal biomass, the fermentation time, and the yeast volume percent are three independent variables that greatly affect bioethanol productivity via anaerobic fermentation. This work optimizes these three individual parameters simultaneously in the range of $30-100 \mathrm{~g} / \mathrm{L}$ algal biomass, $24-72 \mathrm{~h}$ fermentation time, and $15-50$ yeast volume $\% \mathrm{v} / \mathrm{v}$. The results revealed that the optimum conditions for fermentation are $98.7 \mathrm{~g} / \mathrm{L}$ algae containing $45 \%$ carbohydrates, $15.09 \%$ immobilized yeast volume, and $43.6 \mathrm{~h}$ fermentation time in order to achieve $18.57 \mathrm{~g} / \mathrm{L}$ bioethanol in a batch process. The prospective research is going to study the effect of these predicted parameters on continuous fermentation on the semipilot scale.

\footnotetext{
Abbreviations

C.V: Coefficient of variation; G: Algal biomass; HRAP: High rate algal pond; Prob > F: Probability function; $R^{2}$ : Regression coefficient; RSM: Response surface methodology; SHF: Separate hydrolysis fermentation process; T: Fermentation time; V: yeast volume $\%$ V/v; WTP: Wastewater treatment plant
}

\section{Acknowledgements}

The authors would like to express their appreciation to the "National Research Centre (NRC)" for the financial support through the project grant number 11050110 entitled "Production of bioelectricity and biofuelassociated with wastewater treatment using high rate algal pond."

\section{Authors' contributions}

SA studied the synergy of the results, performed statistical analyses, and applied the optimization using response surface methodology (RSM). SM treated the harvested algal biomass, hydrolyzed it by acid, followed up the fermentation process and performed the accompanying analyses. FA tackled the issues of Saccharomyces cerevisiae cultivation, storage, counting, propagation, immobilization and following up its count day by day during fermentation processes. GH is the PI of the project sponsored this work; she contributed to the design of the cultivation and the harvesting system of algae and supervised the whole work. All authors wrote and participated in the development and implementation of the research plan. All authors read and approved the final manuscript.

\section{Funding}

This work was done in the National Research Centre, Egypt, that has funded all the experimental work.

\section{Availability of data and materials}

Not applicable

Ethics approval and consent to participate

Not applicable

\section{Consent for publication}

Not applicable

\section{Competing interests}

The authors declare that they have no competing interests.

\section{Author details}

${ }^{1}$ Chemical Engineering and Pilot Plant Department, National Research Centre, Giza 12622, Egypt. ${ }^{2}$ Water Pollution Research Department, National Research Centre, Giza, Egypt.

Received: 13 August 2019 Accepted: 1 October 2019

Published online: 28 November 2019

\section{References}

Ashokkumar V, Salam Z, Tiwari ON, Chinnasamy S, Mohammed S, Ani FN (2015) An integrated approach for biodiesel and bioethanol production from Scenedesmus bijugatus cultivated in a vertical tubular photobioreactor. Energy Convers Manage 101:778-786

Attfield PV (1977) Stress tolerance: the key to effective strains of industrial baker's yeast. Nat Biotechnol 15:1351-1357

Choi GW, Um HJ, Kang HW (2010) Bioethanol production by a flocculent hybrid, CHFY0321 obtained by protoplast fusion between Saccharomyces cerevisiae and Saccharomyces bayanus. Biomass Bioenerg 34:1232-1242

Crowell EA, Ough CS (1979) A modified procedure for alcohol determination by dichromate oxidation. Am J Enol Vitic 30(1):61-63

Demirbas A (2009) Biofuels securing the planet's future energy needs. Energy Convers Manag 50:2239-2249

Doma HS, Abdo SM, Hemdan BA, Ali GH (2018) Enhancing biomass, energy and value added compounds yield from pilot scale pond system. J Environ Sci Technol 11(4):199-208

Domingues L, Lima N, Teixeira JA (2000) Contamination of a high-cell-density continuous bioreactor. Biotechnol Bioeng 68:584-587

Dubois M, Gilles KA, Hmilton JK, Rebers PA, Smith F (1956) Colorimetric method for the determination of sugars and related substances. Anal Chem 28:350356

El-Dalatony MM, Kurade MB, Abou-Shanab RAl, Kim H, Salama ES, Jeon BH (2016) Long-term production of bioethanol in repeated-batch fermentation of microalgal biomass using immobilized Saccharomyces cerevisiae. Bioresour Technol 219:98-105

El-Naggar ME, Samhan FA, Salama AA, Hamdy RM, Ali GH (2018) Cationic starch: safe and economic harvesting flocculant for microalgal biomass and inhibiting E. coli growth. Int J Biol Macromol 116:1296-1303 
Guo H, Daroch M, Liu L, Qiu G, Geng S, Wang G (2013) Biochemical features and bioethanol production of microalgae from coastal waters of Pearl River Delta. Bioresour Technol 127:422-428

Harun R, Danquah MK, Forde GM (2010) Microalgal biomass as a fermentation feedstock for bioethanol production. J Chem Technol Biotechnol 85:199-203

Ho S, Huang S, Chen C, Hasunuma T, Kondo A, Chang J (2013) Bioethanol production using carbohydrate-rich microalgae biomass as feed stock. Bioresour Technol. 135:191-198

Jin YL, Speers RA (1998) Flocculation of Saccharomyces cerevisiae. Food Res Int 31: $421-440$

John RP, Anisha GS, Nampoothiri KM, Pandey A (2011) Micro and macroalgal biomass: a renewable source for bioethanol. Bioresour Technol 102:186-193

Jorgenson AK, Fiske S, Hubacek K, Li J, McGovern T, Rick T et al (2019) Social science perspectives on drivers of and responses to global climate change. Clim Change 10:1-17

Kasavi C, Finore I, Lama L (2012) Evaluation of industrial Saccharomyces cerevisiae strains for ethanol production from biomass. Biomass Bioenerg 45:230-238

Khalil SRA, Abdelhafez AA, Amer EAM (2015) Evaluation of bioethanol production from juice and bagasse of some sweet sorghum varieties. Ann Agr Sci 60(2): 317-324

Lin Y, Zhang W, Li C (2012) Factors affecting ethanol fermentation using Saccharomyces cerevisiae BY4742. Biomass Bioenerg 47:395-401

Lu J, Sheahan C, Fu P (2001) Metabolic engineering of algae for fourth generation biofuels production. Energy Environ Sci 4(7):2451

Markou G, Angelidaki E, Nerantzis E, Georgakakis D (2013) Bioethanol production by carbohydrate-enriched biomass of Antrospira (Spirulina) platensis. Energies 6:3937-3950

Montgomery DC (2003) Introduction to factorial design. Design and analysis of experiments, fifth ed. John Wiley and Sons Inc, In, pp 170-228

Nigam PS, Singh A (2011) Production of liquid biofuels from renewable resources. Prog Energy Combust Sci 37:52-68

Pejin D, Mojovic LC (2009) Vucurovic V. Fermentation of wheat and triticale hydrolysates: a comparative study Fuel 88:1625-1628

Renewable Fuels Association US (2018) Global ethanol production. http://www. afdc.energy.gov/data/, (Last update 30 Oct. 2018, Accessed 9 March 2019).

Silva CEF, Bertucco A (2016) Bioethanol from microalgae and cyanobacteria: a review and tecnhological outlook. Process Biochem 51:1833-1842

Silva CEF, Meneghello D, Bertucco A (2018) A systematic study regarding hydrolysis and ethanol fermentation from microalgal biomass. Biocatal Agric Biotechnol 14:172-182

Staniszewski M, Kujawski W, Lewandowska M (2007) Ethanol production from whey in bioreactor with co-immobilized enzyme and yeast cells followed by pervaporative recovery of product - kinetic model predictions. J Food Eng 82:618-625

Tan KT, Lee KT, Mohamed AR (2008) Role of energy policy in renewable energy accomplishment: the case of second-generation bioethanol. Energy Policy 36:3360-3365

Tofighi A, Assadi MM, Asadirad MHA, Karizi SZ (2014) Bio-ethanol production by a novel autochthonous thermo-tolerant yeast isolated from wastewater. Environ Health Sci Eng 12: 107.D.

Wolske KS, Stern PC (2018) Contributions of psychology to limiting climate change: opportunities through consumer behavior. Psychology and climate change, human perceptions, impacts, and responses, In, pp 127-160

Yusuf C (2007) Biodiesel from microalgae. Biotechnol Adv 25(3):294-306

\section{Publisher's Note}

Springer Nature remains neutral with regard to jurisdictional claims in published maps and institutional affiliations.

\section{Submit your manuscript to a SpringerOpen ${ }^{\circ}$ journal and benefit from:}

- Convenient online submission

- Rigorous peer review

- Open access: articles freely available online

- High visibility within the field

- Retaining the copyright to your article

Submit your next manuscript at $\boldsymbol{\nabla}$ springeropen.com 